CATALLAXY

Volume 3 Issue 1 June 2018

e-ISSN 2544-090X

¿ www.catallaxy.pl

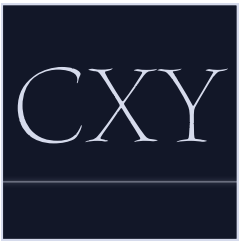

Oryginalny artykut naukowy

otrzymano: 08.04.2018 / zaakceptowano: 25.06.2018 / opublikowano online: 30.06 .2018

Prus, R. (2018). Wplyw brexitu na gospodarkę Wielkiej Brytanii. Catallaxy, 3(1): 41-53. doi:10.24136/cxy.2018.007.

\title{
Wpływ brexitu na gospodarkę Wielkiej Brytanii
}

\author{
ROBERT PRUS \\ Uniwersytet Mikotaja Kopernika w Toruniu, ul. Gagarina 13a, 87-100 Toruń, Polska \\ \robert.prus.torun@gmail.com \\ (D) orcid.org/0000-0003-1865-2798
}

\begin{abstract}
Abstrakt
Motywacja: W referendum przeprowadzonym 23 czerwca 2016 roku, Brytyjczycy zadecydowali o wystąpieniu Wielkiej Brytanii z Unii Europejskiej (UE). Dotychczas, tylko dwa państwa odłączyły się od struktur unijnych, tj. Grenlandia oraz Algieria. Analiza brexitu pozwoli na wyjaśnienie procedur i konsekwencji związanych z wystąpieniem danego państwa ze struktur unijnych. Ponadto, opuszczenie ugrupowania przez wysoko rozwinięte państwo o silnej pozycji na arenie międzynarodowej, może spowodować wyraźne skutki nie tylko polityczne, ale również ekonomiczne dla całej Europy.

Cel: Celem artykułu jest wykazanie potencjalnego wpływu brexitu na poszczególne zmienne makroekonomiczne odzwierciedlające stan brytyjskiej gospodarki. Analizie poddano: stopę wzrostu gospodarczego mierzoną PKB, stopę inflacji mierzoną wskaźnikiem CPI (Consumer Price Index), kurs walutowy GBP/PLN, procesy migracyjne, finanse publiczne, bezpośrednie inwestycje zagraniczne (BIZ) oraz handel zagraniczny Zjednoczonego Królestwa.

Materiały i metody: W artykule wykorzystano różne źródła i metody badawcze. Część teoretyczną oparto na artykułach naukowych oraz źródłach internetowych. Materiał empiryczny stanowią dane publikowane przez ONS, OECD oraz Oficjalny Portal Unii Europejskiej. Do zastosowanych metod badawczych można zaliczyć analizę opisową oraz analizę wybranych wskaźników makroekonomicznych.

Wyniki: Przeprowadzona analiza wykazała, że brexit niewątpliwie będzie miał wpływ na stan gospodarki Wielkiej Brytanii, a skala spowolnienia zależy od wyboru przez rząd brytyjski modelu, określającego stopień powiązań z rynkiem unijnym. Do skutków brexitu można zaliczyć wolniejsze tempo wzrostu PKB, wzrost stopy inflacji, deprecjację GBP, zmniejszenie napływu imigrantów oraz odpływ BIZ na rzecz innych państw.
\end{abstract}

Stowa kluczowe: brexit; Wielka Brytania; referendum JEL: FOO; EOO; HOO

\section{Wprowadzenie}

Wielka Brytania przystąpiła do Europejskiej Wspólnoty Gospodarczej (EWG) w 1973 roku. Dwa lata później, 5 czerwca 1975 roku, w Zjednoczonym Królestwie przeprowadzono pierwsze referendum $w$ sprawie dalszego członkowska w EWG. Referendum zakończyło się zdecydowanym zwycięstwem zwolenników pozostania we wspólnocie (ponad 67\% głosujących) (Musiał-Karg, 2016, s. 9).

23 czerwca 2016 roku przeprowadzono kolejne referendum dotyczące członkostwa tego państwa w Unii Europejskiej (UE), którego wynik zakończył się nieznacznym zwycięstwem zwolenników opuszczenia UE (51,9 \% głosujących, tj. 17,4 mln osób). Za wyjściem 
z UE głosowali głównie ludzie starsi (60\% w grupie osób powyżej sześćdziesiątego roku życia, 27\% w grupie wiekowej 18-24 lata) oraz słabiej wykształceni.

Terminem „brexit”, który powstał z połączenia słów British oraz exit, określa się proces opuszczania przez Wielką Brytanię struktur UE zapoczątkowany referendum w czerwcu 2016 roku. Przyczyn brexitu należy się doszukiwać po stronie finansowej oraz społecznej (Makuch, 2017, s. 1). Zwolennicy wystąpienia z UE argumentowali, że stworzy to możliwość poprawy bilansu handlowego poprzez uwolnienie gospodarki $z$ unijnych regulacji oraz wynegocjowanie porozumień handlowych z państwami rozwijającymi się (Konopczak, 2016, s. 19). Jako kolejną przyczynę należy wymienić obietnicę ograniczenia tempa imigracji, która według Brytyjczyków była odpowiedzialna za stagnację wynagrodzeń realnych oraz postrzegana jako obciążenie dla systemu świadczeń społecznych. Przed referendum głoszono hasła, że dzięki wyjściu z UE, Wielka Brytania nie będzie musiała płacić kwoty 350 mln GBP tygodniowo na rzecz budzetu unijnego, a środki te zasiliłyby brytyjską służbę zdrowia. W rzeczywistości, składka w 2016 roku wynosiła 252 tys. GBP tygodniowo, zaś do Wielkiej Brytanii, w formie funduszy unijnych, wracało 81 tys. GBP z tej kwoty.

Zgodnie $z$ art. 50 Traktatu o Unii Europejskiej (TUE, 2012), określającego procedurę wystąpienia państwa członkowskiego z UE, 29 marca 2017 roku T. May, premier Zjednoczonego Królestwa, podpisała list, który przekazano D. Tuskowi, przewodniczącemu Rady Europejskiej (Polska Times, 2018). Następnie na podstawie art. 218 Traktatu o funkcjonowaniu Unii Europejskiej (TFUE, 2012), zaczęto negocjować umowę określającą warunki wystąpienia oraz przyszłe relacje z UE. Negocjacje w sprawie brexitu przebiegają etapowo. W pierwszej fazie rozwiązano kwestię wzajemnych rozliczeń finansowych oraz praw Brytyjczyków w UE i obywateli UE w Wielkiej Brytanii. W drugiej fazie zostaną określone wzajemne stosunki gospodarcze. $\mathrm{W}$ dniu wejścia w życie umowy o wystąpieniu (lub po upływie dwóch lat od daty przekaza- nia listu do Rady Europejskiej i braku porozumienia), państwo członkowskie przestaje być zobowiązane postanowieniami traktatów. Istnieje jednak możliwość przedłużenia dwuletniego okresu w przypadku porozumienia między UE oraz państwem występującym (Pera, 2017, s. 74).

Celem artykułu jest wykazanie potencjalnego wpływu brexitu na poszczególne zmienne makroekonomiczne odzwierciedlające stan brytyjskiej gospodarki.

Zakres czasowy artykułu stanowią lata 2003-2018. Wybór ten podyktowany został faktem, że do jednej z przyczyn brexitu zalicza się problemy migracyjne, zapoczątkowane największym rozszerzeniem UE, które przeprowadzono w 2004 roku.

W sekcji 2. dokonano przeglądu literatury przedmiotu. W sekcji 3. opisano wykorzystane materiały i metody badawcze. W sekcji 4. przedstawiono wyniki przeprowadzonych analiz, które podsumowano w sekcji 5 .

\section{Przegląd literatury}

B. Pera (2017), określa warunki i wskazuje potencjalne skutki dla wymiany handlowej między UE i Wielką Brytanią będące następstwem uruchomienia procedury opuszczenia ugrupowania przez to państwo. Autorka uważa, że prawdopodobne konsekwencje brexitu mogą mieć o wiele szerszy wymiar niż tylko dla bezpośrednich relacji UE i Zjednoczonego Królestwa. Konsekwencją tych działań może być nawet pogłębienie procesów dezintegracyjnych w UE.

M. Makuch (2017), wskazuje możliwe warianty ukształtowania relacji Wielkiej Brytanii z UE po jej wystąpieniu oraz próbuje ocenić potencjalne konsekwencje dla polskiej gospodarki i przyszłych relacji brytyjsko-polskich w świetle brexitu.

K. Czech i M. Wielechowski (2017), przedstawili wpływ wyniku referendum z 23 czerwca 2016 roku na stan gospodarki i finansów Wielkiej Brytanii. Wykazano, że wynik referendum przyczynił się do wystąpienia rekordowego poziomu indeksu niepewno- 
ści polityki gospodarczej w Zjednoczonym Królestwie.

E. Bombińska (2017), analizuje potencjalne skutki wyjścia Wielkiej Brytanii z UE w obszarze napływu bezpośrednich inwestycji zagranicznych (BIZ) do tego państwa. Autorka uważa, że przyszłe relacje handlowe między Wielką Brytanią a państwami członkowskimi, ze względu na istniejący poziom integracji handlowych, będą oparte na wspólnym rynku. $Z$ tego powodu obniżenie napływu BIZ do Zjednoczonego Królestwa może przyjąć ograniczone rozmiary.

J. Kundera (2017), analizuje przyczyny i najważniejsze konsekwencje ekonomiczne brexitu. W swoich badaniach używa metodologii non-Europe, biorąc pod uwage, że to, co obecnie jest korzyścią $z$ integracji, $w$ przyszłości może okazać się kosztem dezintegracji. Ostateczny bilans kosztów i korzyści brexitu zależał będzie od kształtu finalnego porozumienia między UE a Wielką Brytanią.

A. Michalik (2017), analizuje strukturę handlu zagranicznego Wielkiej Brytanii i Polski w celu określenia czy brexit wywoła negatywne konsekwencje dla brytyjskiego handlu zagranicznego oraz czy Polska może w przyszłości podążyć drogą wyznaczoną przez to państwo. Dochodzi do wniosku, że brytyjski rynek zbytu jest jednym z ważniejszych dla polskich eksporterów. Ewentualne pogorszenie warunków wymiany handlowej, może stanowić istotny problem dla wielu polskich przedsiębiorstw.

\section{Materiały i metody}

W artykule wykorzystano różne źródła i metody badawcze. Część teoretyczną oparto na artykułach naukowych oraz źródłach internetowych. Materiał empiryczny stanowią dane publikowane przez ONS (2018), OECD (2018) oraz Oficjalny Portal Unii Europejskiej (2018). Do zastosowanych metod badawczych można zaliczyć analizę opisową oraz analizę wybranych wskaźników makroekonomicznych.
4. Wyniki badania

4.1. Wpływ brexitu na stopę wzrostu gospodarczego i stopę inflacji w Wielkiej Brytanii

Na wykresie 1. zaprezentowano stopę wzrostu gospodarczego w Wielkiej Brytanii, Niemczech oraz Stanach Zjednoczonych mierzoną PKB w latach 2015-2017. Na podstawie analizy danych zawartych na wykresie 1 . można wyciągnąć wniosek, że tempo wzrostu PKB w Wielkiej Brytanii było najniższe spośród analizowanych państw. Mogło być to spowodowane zmniejszeniem inwestycji, które wywołane zostało obawą przedsiębiorców o spadek podaży pracy po brexicie, mimo najniższej stopy bezrobocia od 1975 roku (4,2\% w IV kwartale 2017 roku) (Wyborcza, 2018).

W celu pobudzenia gospodarki poprzez wywołanie wzrostu podaży pieniądza, a w efekcie wzrostu konsumpcji i inwestycji, rozszerzono program luzowania ilościowego o 70 mld GBP, do łącznej kwoty 435 mld GBP (Czech i Wielechowski, 2017, s. 25). Gospodarkę Wielkiej Brytanii, od deprecjacji GBP, uchronił napływ turystów, głównie ze Stanów Zjednoczonych i Chin (ONS, 2018).

Prognozy dotyczące przyszłego PKB Wielkiej Brytanii zależą od scenariusza, który zostanie wybrany przez to państwo w sprawie relacji handlowych $z$ UE. Według raportu brytyjskiego rządu o skutkach brexitu, jeżeli Zjednoczone Królestwo pozostanie na unijnym, wspólnym rynku, poziom brytyjskiego wskaźnika wzrostu gospodarczego obniży się o 2 p.p. W przypadku podpisania kompleksowej umowy o wolnym handlu $z$ UE, strata wyniesie 5 p.p. Natomiast przy wyborze relacji na podstawie ogólnych reguł Światowej Organizacji Handlu (World Trade Organization, WTO), aż 8 p.p. (The Times, 2018).

$\mathrm{Na}$ wykresie 2. zaprezentowano stopę inflacji w Wielkiej Brytanii, Niemczech oraz Stanach Zjednoczonych mierzoną wskaźnikiem cen towarów i usług konsumpcyjnych (Consumer Price Index, CPI) w latach 20152017. Przed referendum, które odbyło się w czerwcu 2016 roku, stopa inflacji oscylowała 
w granicy 0,4\%. W drugiej połowie 2016 roku nastąpił silny wzrost poziomu tego wskaźnika (do około 1,5\%). Gdy poziom wskaźnika CPI wzrósł do poziomu celu inflacyjnego wynoszącego 2,0\%, władze Banku Anglii, 4 sierpnia 2016 roku, podjęły nietypową decyzję. Obniżono poziom głównej stopy procentowej o 25 p.p. Dopiero 2 listopada 2017 roku zarząd banku przywrócił stopy procentowe do poziomu sprzed referendum, tj. 0,5\%, dokonując tym samym pierwszej podwyżki stóp od dekady (Trading Economics, 2018).

\subsection{Wpływ brexitu na kurs walutowy GBP/PLN}

Na wykresie 3. przedstawiono kwartalny kurs GBP/PLN w latach 2015-2017. Na koniec 2015 roku kurs GBP/PLN przekraczał poziom 5,9. Od momentu ogłoszenia wyniku referendum, poziom kursu cechowała tendencja spadkowa $z$ krótkookresowymi wzrostami. Inwestorzy podkreślali, że wiele niewiadomych dotyczących postanowień w sprawie brexitu stanowi duze ryzyko związane z kupowaniem GBP w celach spekulacyjnych (Wyborcza, 2018).

Poziom brytyjskiej waluty względem EUR obniżył się od czerwca 2016 do marca 2018 o około 12\% (Bankier, 2018). Była to negatywna informacja dla Brytyjczyków, którzy planowali wycieczki zagraniczne lub zakup importowanych produktów oraz dla obywateli państw członkowskich, pracujących na wyspach, którzy wysyłali regularnie środki do swoich rodzin.

$\mathrm{Na}$ osłabieniu GBP straciły przedsiębiorstwa importerskie, zyskały zaś luksusowe, brytyjskie marki, które notowały rekordowe obroty, po części za sprawą chińskich turystów (Wyborcza, 2018). Import oraz eksport Wielkiej Brytanii opisano w sekcji 4.6.

\subsection{Wpływ brexitu na procesy migracyjne w Wielkiej Brytanii}

Od 2004 roku, kiedy brytyjski rynek pracy otwarto dla innych państw europejskich takich, jak: Polska, Węgry i Czechy, Zjednoczone Królestwo doświadczyło fali imigracji na niespotykaną w latach poprzednich skalę. $\mathrm{Na}$ wykresie 4. przedstawiono zestawienie imigracji oraz emigracji Wielkiej Brytanii w latach 2003-2017. Analizując dane można zauważyć, że w 2003 roku do Zjednoczonego Królestwa przybyło 511 tys. imigrantów, zaś w 2004 roku liczba ta zwiększyła się o 78 tys. osób. Znaczny napływ imigrantów (652 tys. osób rocznie), który przedstawiono w czerwcowym raporcie Office for National Statistics (ONS, 2018) z 2016 roku był jednym $z$ argumentów zwolenników brexitu, którym tłumaczono przeciążenie służby zdrowia oraz mniejszą dostępność mieszkań i szkół dla Brytyjczyków.

Ze statystyk opublikowanych przez ONS (2018) wynika, że po referendum w sprawie brexitu, napływ imigrantów do Wielkiej Brytanii zmalał o 80 tys. rocznie (do 572 tys. w czerwcu 2017 roku). Za niższe saldo migracji (o 106 tys. osób w stosunku do czerwca 2016 roku), odpowiadała mniejsza liczba przyjazdów obywateli UE do Zjednoczonego Królestwa w celach zarobkowych. Od czerwca 2016 roku do czerwca 2017 roku z powodów tych do Wielkiej Brytanii imigrowało o 47 tys. mniej mieszkańców państw UE w obawie przed niepewną polityką migracyjną oraz niestabilnym kursem GBP (ONS, 2018). Z raportów opublikowanych przez ONS (2018) wynika, że liczba osób przyjeżdzających na studia do Wielkiej Brytanii z państw UE nie zmniejszyła się, a utrzymywała się na poziomie 33 tys. osób rocznie. Praca oraz chęć studiowania były głównymi przyczynami, dla których imigranci przybywali do Zjednoczonego Królestwa.

W grudniu 2017 roku zakończono pierwszą fazę negocjacji między Wielką Brytanią a UE w sprawie brexitu, zaś 19 marca 2018 roku wynegocjowano wstępne porozumienie dotyczące okresu przejściowego, tj. czasu między ostatecznym opuszczeniem UE przez Wielką Brytanię a zawarciem nowej, brytyjsko-unijnej umowy handlowej. Podczas okresu przejściowego, tzn. od 29 marca 2019 roku do 31 grudnia 2020 roku, Wielka Brytania będzie zobowiązana do poszanowania integralności wspólnego rynku i jego czterech 
swobód, tj. przepływu usług, towarów, osób i kapitału. Ponadto, regulacje przyjęte przez państwa członkowskie $\mathrm{w}$ trakcie obowiązywania okresu przejściowego, będą również dotyczyły Wielkiej Brytanii. Z chwilą formalnego wyjścia z UE, Zjednoczone Królestwo stanie się państwem trzecim, które straci możliwość udziału $\mathrm{w}$ procesach decyzyjnych unijnych instytucji (Wyborcza, 2018). Po pierwszej fazie negocjacji osiągnięte porozumienie zapewnia prawa ponad milionowi Brytyjczyków na terenach państw członkowskich oraz ponad trzem milionom obywateli UE w Wielkiej Brytanii. Według ustalonej umowy (Oficjalny Portal Unii Europejskiej, 2018):

- obywatele UE i Wielkiej Brytanii oraz członkowie ich rodzin będą upoważnieni do dożywotniego korzystania ze swoich praw, mających źródło $\mathrm{w}$ przepisach prawa UE, jeżeli przed 31 grudnia 2020 roku przeprowadzą się na terytorium innego państwa;

- obywatele zachowają prawo do emerytury, opieki medycznej i świadczeń z tytułu zabezpieczenia społecznego;

- prawa obywateli w UE będą monitorowane przez Komisję Europejską, zaś w Wielkiej Brytanii będzie za to odpowiedzialny niezależny organ krajowy;

- obywatele, którzy nie posiadają lub do określonego dnia nadal nie będą posiadać stałego pobytu, tzn. że nie mieszkają w danym państwie powyżej 5 lat, w dalszym ciągu będą mogli się o nie ubiegać, nawet po wystąpieniu Zjednoczonego Królestwa $z \mathrm{UE}$;

- prawa dzieci, rodziców, dziadków, wnuków, współmałżonków, zarejestrowanych partnerów oraz osób pozostających w stałym związku, dalej będą podlegały ochronie, nawet mimo tego, że obecnie osoby te nie mieszkają w tym samym państwie, co obywatele UE lub Wielkiej Brytanii, ale są w stanie zamieszkać razem w przyszłości.

Dotychczasowe ograniczenie imigracji do Wielkiej Brytanii z państw członkowskich nie oznacza, że gospodarka Zjednoczonego Królestwa na tym jednoznacznie skorzysta lub straci. $Z$ jednej strony, spowoduje to zredu- kowanie świadczeń socjalnych, z drugiej zaś, zmaleją wpływy do budżetu państwa z podatków. Państwa członkowskie, dzięki mniejszej emigracji, zyskają wykwalifikowaną siłę roboczą, ale może to doprowadzić do braku równowagi na lokalnym rynku pracy.

\subsection{Wpływ brexitu na finanse publiczne Wielkiej Brytanii}

W obawie przed przyszłym spowolnieniem wzrostu gospodarczego, spowodowanym brexitem, w najbliższych latach w Wielkiej Brytanii może dojść do wzrostu długu publicznego, ponieważ rząd zapowiada liczne inwestycje publiczne, które mają za zadanie przyspieszyć tempo wzrostu $\mathrm{PKB}$, m.in.: rozbudowę mieszkalnictwa, wznowienie budowy elektrowni atomowej, unowocześnienie lotnisk i kolei. Inwestycje będą finansowane emisją obligacji długoterminowych (Kundera, 2017, s. 71).

Ponadto, na podstawie raportu dotyczącego zakończenia pierwszej fazy negocjacji, Wielka Brytania, po opuszczeniu UE, jest zobowiązana do uregulowania wszystkich należności wobec UE wynikających z jej udziału $w$ obecnym budżecie oraz wieloletnich, unijnych programach pomocowych, m.in. dla Ukrainy. Ustalono, że w wyniku brexitu żadne $z$ państw członkowskich nie otrzyma mniejszej kwoty w ramach budżetu, ani nie będzie musiało zapłacić większych składek. Szacuje się, że kwota wynikająca z porozumienia może sięgać 45 mld EUR (Oficjalny Portal Unii Europejskiej, 2018).

\subsection{Wpływ brexitu na BIZ Wielkiej Brytanii}

W 2005 roku Wielka Brytania zajmowała pierwsze miejsce pod względem napływu BIZ. W 2016 roku pod tym względem lepsze okazały się Stany Zjednoczone (OECD, 2018). $\mathrm{Na}$ wykresie 5. i wykresie 6. przedstawiono odpowiednio kwartalne zestawienie odpływów i napływów BIZ w Wielkiej Brytanii, Niemczech i Stanach Zjednoczonych w latach 2015-2017. Z analizy danych można wyciągnąć wniosek, że po ogłoszeniu wyników re- 
ferendum, w Wielkiej Brytanii odnotowano masowy odpływ BIZ na rzecz innych państw.

$Z$ raportu opracowanego przez przedsiębiorstwo EY (2018) wynika, że wraz z pojawieniem się możliwości opuszczenia UE przez Wielką Brytanię, głównym czynnikiem atrakcyjności BIZ w Wielkiej Brytanii, stawał się dostęp do rynku wewnętrznego UE. W 2014 roku wskazało go $63 \%$ respondentów, w 2015 - 72\%, zaś w 2016 - 79\% (Bombińska, 2017, s. 186). Na pytanie o wzrost atrakcyjności Wielkiej Brytanii w zakresie BIZ w przeciągu trzech lat, w 2015 roku 54\% respondentów odpowiedziało twierdząco, jednak w 2016 roku było to już tylko 36\% (EY, 2018).

W 2015 roku struktura BIZ w Wielkiej Brytanii była zdominowana przez UE (40,0\%) oraz Stany Zjednoczone (23,5\%). W 2016 roku doszło do minimalnej, dodatniej zmiany procentowej na rzecz państw Azjatyckich (ONS, 2018).

$\mathrm{Na}$ wykresie 7. przedstawiono podział BIZ dokonanych przez UE w Wielkiej Brytanii pod względem sektorów gospodarki w 2016 roku. Na podstawie analizy danych zawartych na wykresie 7. można stwierdzić, że w 2016 roku UE inwestowała głównie w brytyjski przemysł (21,3\%) oraz branżę finansów i ubezpieczeń (9,9\%).

Dzięki napływowi kapitału $z$ innych państw, Londyn można nazwać finansową stolicą Europy. W Wielkiej Brytanii funkcjonuje około 540 banków, a w samej stolicy działają największe $z$ nich. Ponadto, Londyn jest siedzibą około jednej trzeciej z 500 największych, światowych przedsiębiorstw. Brexit, dla wszystkich tych przedsiębiorstw oraz banków może stanowić spore wyzwanie, ponieważ mogą pojawić się problemy z obsługą finansową oddziałów europejskich, a w najgorszej sytuacji, banki mogą stracić tzw. paszport bankowy, który zapewnia swobodę sprzedaży ich usług na całym, jednolitym rynku. Szacuje się, $\dot{z}$ e po brexicie $z$ sektora finansowego Zjednoczonego Królestwa może ubyć nawet 100 tys. miejsc pracy, a centrum finansowym Europy zostanie Frankfurt nad Menem (Kundera, 2017, s. 66).
4.6. Wpływ brexitu na handel zagraniczny Wielkiej Brytanii

Wzrost wolumenu wymiany handlowej, który jest następstwem integracji gospodarczej, pomaga ocenić stopień współzależności między państwami członkowskimi. W 2016 roku brytyjski eksport do UE stanowił $47,0 \%$ całkowitego eksportu, a import z UE $-51,9 \%$ całkowitego importu (wykres 8.). Opierając się wyłącznie na tych danych można wyciągnąć błędne wnioski.

$Z$ raportu opublikowanego przez ONS (2018) wynika, że udział UE w strukturze brytyjskiego eksportu od 2006 roku (62,6\%) nieustannie malał na rzecz Stanów Zjednoczonych (w 2016 roku - 15,0\%), Chin (w 2016 roku - 4,4\%) oraz Szwajcarii (w 2016 roku $-4,8 \%$ ). UE, rozpatrywana jako jeden podmiot, stanowi największy rynek zbytu dla brytyjskich towarów. Jednak, gdyby dokonano podziału na poszczególne państwa członkowskie okazuje się, że to Stany Zjednoczone znajdują się na pierwszym miejscu (Michalik, 2017, s. 97).

Dotychczas nie określono wzajemnych relacji handlowych między Wielką Brytania a UE. Istnieją jednak cztery modele, które określają stopień powiązań $z$ rynkiem unijnym: norweski, szwajcarski, turecki i oparty na zasadach WTO (Pera, 2017, s. 77).

Według modelu norweskiego, Wielka Brytania miałaby zapewniony dostęp do wspólnego rynku (m.in. swobodę przepływu ludzi). Musiałaby zaakceptować wszystkie prawa, które są tworzone w UE, bez możliwości wpływania na nie oraz byłaby zobligowana do płacenia składki członkowskiej (około 80\% obecnej). Wielka Brytania miałaby większą swobodę przy zawieraniu umów z państwami trzecimi oraz nie musiałaby uczestniczyć we wspólnej polityce zagranicznej i bezpieczeństwa UE. Według wielu zwolenników brexitu, rozwiązanie to doprowadziłoby do ograniczenia suwerenności państwa.

Zgodnie z modelem szwajcarskim, Wielka Brytania nie byłaby członkiem unii celnej ani stroną umów handlowych między UE a państwami trzecimi. Byłaby zobowiązana do uisz- 
czania składek do unijnego budżetu (około $40 \%$ obecnej) oraz musiałaby zezwolić na częściowy dostęp do wspólnego rynku. Zjednoczone Królestwo nie miałoby reprezentantów $\mathrm{w}$ instytucjach unijnych i nie brałoby udziału w głosowaniach w Radzie UE.

Według modelu tureckiego Wielka Brytania byłaby członkiem unii celnej, lecz nie miałaby wpływu na poziom ceł nakładanych przez UE na towary pochodzące spoza niej. Nie musiałaby także dokonywać wpłat na rzecz budżetu unijnego, nie miałyby wpływu na unijne prawo, a przepływ ludności byłby ograniczony.

Relacje między UE a Wielką Brytanią mogłyby być oparte na zasadach WTO. Zjednoczone Królestwo nie wnosiłoby opłat do budżetu unijnego, jednak oznaczałoby to wzrost ceł na różne produkty (cła objęłyby około $90 \%$ towarów eksportowanych do UE). Wielka Brytania mogłaby ograniczyć przepływ ludności. Ten rodzaj porozumienia jest najmniej korzystny dla Wielkiej Brytanii, ze względu na ograniczenie konkurencyjności brytyjskich eksporterów oraz prawdopodobne zmniejszenie BIZ.

W zależności od wybranego modelu należy pamiętać, że UE ma wynegocjowane, liczne umowy o wolnym handlu $z$ wieloma państwami, a w momencie odłączenia się Wielkiej Brytanii od UE, zgodnie z prawem międzynarodowym, wszystkie umowy $z$ państwami trzecimi wygasają. Zjednoczone Królestwo musiałoby wynegocjować około 759 umów ze 168 państwami spoza UE (Wyborcza, 2018).

\section{Zakończenie}

Ostateczna umowa określająca wzajemne relacje między UE oraz Wielką Brytanią nie została jeszcze ustalona, jednak, ze wszystkich prognoz wynika, że sytuacja ekonomiczna Zjednoczonego Królestwa w krótkookresowej perspektywie nie poprawi się na skutek opuszczenia UE. Zwolennicy brexitu uważają, $\dot{z}$ e potencjalne straty, poniesione na rynku unijnym, zostaną zrekompensowane poprzez zawarcie umowy o wolnym handlu ze Stanami
Zjednoczonymi, które obecnie charakteryzują się podejściem protekcjonistycznym, a także Chinami, których pozycja $\mathrm{w}$ handlu światowym nieustannie się umacnia.

Z raportu brytyjskiego rządu wynika, $\dot{z}$ e brexit najbardziej wpłynie na branżę chemiczną, samochodową oraz gastronomiczną. Jednak to, co nastąpi w długookresowej perspektywie, zależy od wyboru modelu powiązań $z$ rynkiem unijnym oraz decyzji przedsiębiorstw odnośnie przyszłych inwestycji.

Wynik referendum $w$ sprawie wyjścia Wielkiej Brytanii z UE skutkował dla wysp spowolnieniem tempa wzrostu PKB, znacznym wzrostem wskaźnika cen, spadkiem wartości GBP względem innych walut, ograniczeniem napływu imigrantów oraz masowym odpływem BIZ.

\section{Bibliografia}

Bankier. (2018). Pobrane 26.03.2018 z https://www. bankier.pl.

Bombińska, E. (2017). Brexit a bezpośrednie inwestycje zagraniczne w Wielkiej Brytanii. Horyzonty Polityki, 8(22). doi:10.17399/ HP.2017.082209.

Czech, K., i Wielechowski, M. (2017). Brexit a sytuacja ekonomiczna Wielkiej Brytanii. Zeszyty Naukowe Szkoty Głównej Gospodarstwa Wiejskiego w Warszawie. Problemy Rolnictwa Światowego, 17(1). doi:10.22630/prs.2017.17.1.2.

EY. (2018). Pobrane 27.03.2018 z http://www. ey.com.

Konopczak, K. (2016). Brexit: tło ekonomiczne i społeczne. Unia Europejska.pl, 4(239).

Kundera, J. (2017). Brexit. Ekonomia XXI wieku, 2(14). doi:10.15611/e21.2017.2.04.

Makuch, M. (2017). Nowe relacje brytyjsko-unijne w świetle brexitu. Skutki dla Polski. Studia i Praca WNEiZ US, 49(2). doi:10.18276/ sip.2017.49/2-11.

Michalik, A. (2017). Brexit a wymiana handlowa Wielkiej Brytanii: wnioski dla Polski. Horyzonty Polityki, 8(22).

Musiał-Karg, M. (2016). Operacje brexit. Brytyjskie referenda z 1975 i 2016 roku. Acta Politica Polonica, 3(37). doi:10.18276/ap.2016.37-01.

NBP. (2018). Pobrane 26.03.2018 z http://www. nbp.pl.

OECD. (2018). Pobrane 25.03.2018 z http://www. oecd.org. 
Oficjalny Portal Unii Europejskiej. (2018). Pobrane 26.03.2018 z http://europa.eu.

ONS. (2018). Pobrane 27.03.2018 z https://www. ons.gov.uk.

Pera, B. (2017). Brexit a wymiana handlowa Unii Europejskiej i Wielkiej Brytanii. Horyzonty Polityki, 8(22).

Polska Times. (2018). Pobrane 25.03.2018 z http:// www.polskatimes.pl.

The Times. (2018). Pobrane 27.03.2018 z https:// www.thetimes.co.uk.

Trading Economics. (2018). Pobrane 27.03.2018 $z$ https://tradingeconomics.com.

Traktat o funkcjonowaniu Unii Europejskiej (OJ C 326, 26.10.2012).

Traktat o Unii Europejskiej (OJ C 326, 26.10.2012).

WTO. (2018). Pobrane 25.03.2018 z http://www. wto.org.
Wyborcza. (2018). Pobrane 26.03.2018 z http:// wyborcza.pl.

Informacje uzupełniające

Wkład autorski: autor zaakceptował ostateczną wersję artykułu.

Źródła finansowania: artykuł został w całości sfinansowany ze źródeł Uniwersytetu Mikołaja Kopernika w Toruniu.

Uwagi: wyniki badania byly zaprezentowane na VIIl Ogólnopolskiej Konferencji Naukowej z cyklu Problemy gospodarki światowej (Toruń, 20.04.2018) 


\section{Aneks}

Wykres 1.

Roczna stopa wzrostu gospodarczego mierzona PKB w Wielkiej Brytanii, Niemczech i Stanach Zjednoczonych w latach 2015-2017 (w\%)

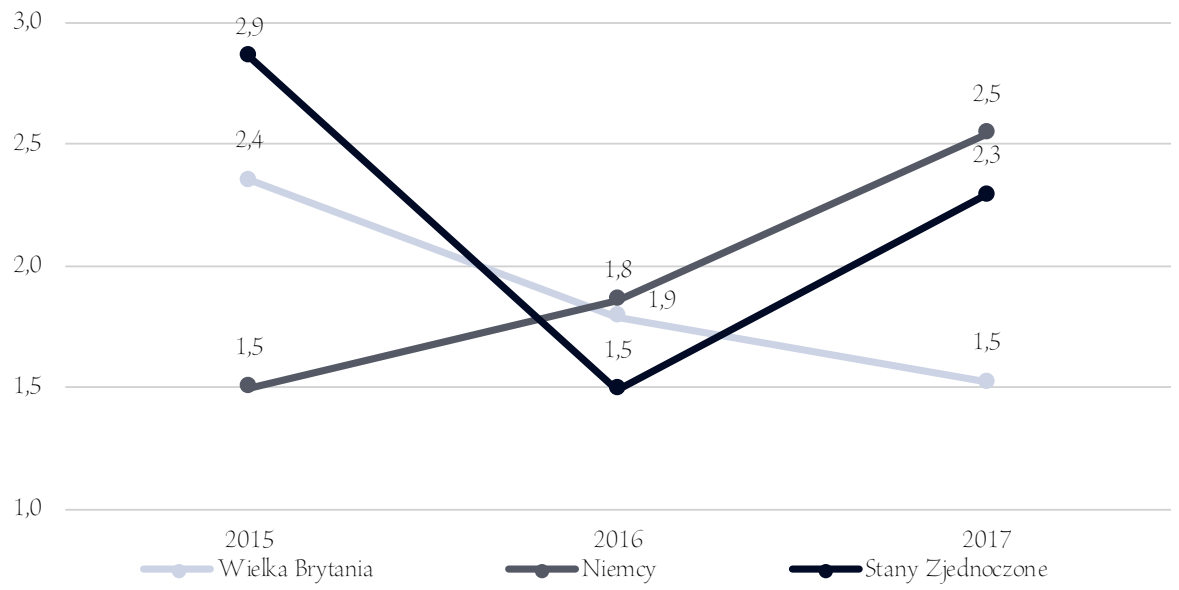

Źródło: Opracowanie własne na podstawie OECD (2018).

\section{Wykres 2.}

Kwartalna stopa inflacji mierzona wskaźnikiem CPI w Wielkiej Brytanii, Niemczech i Stanach Zjednoczonych w latach 2015-2017 (w \%)

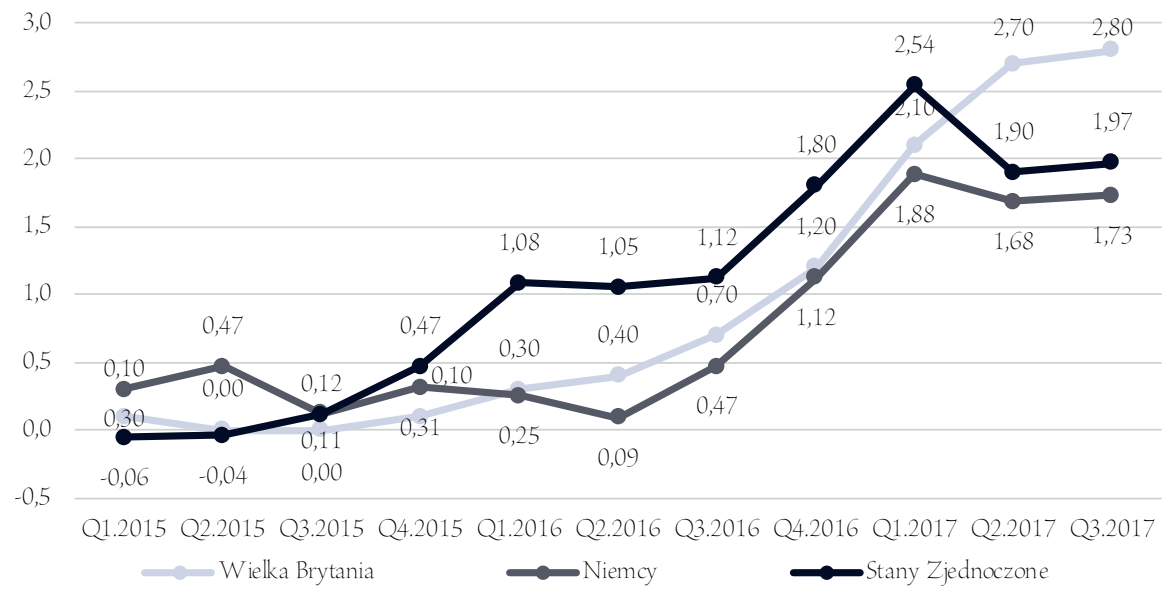

Źródło: Opracowanie własne na podstawie OECD (2018) 
Wykres 3.

Kwartalny kurs GBP/PLN w latach 2015-2017

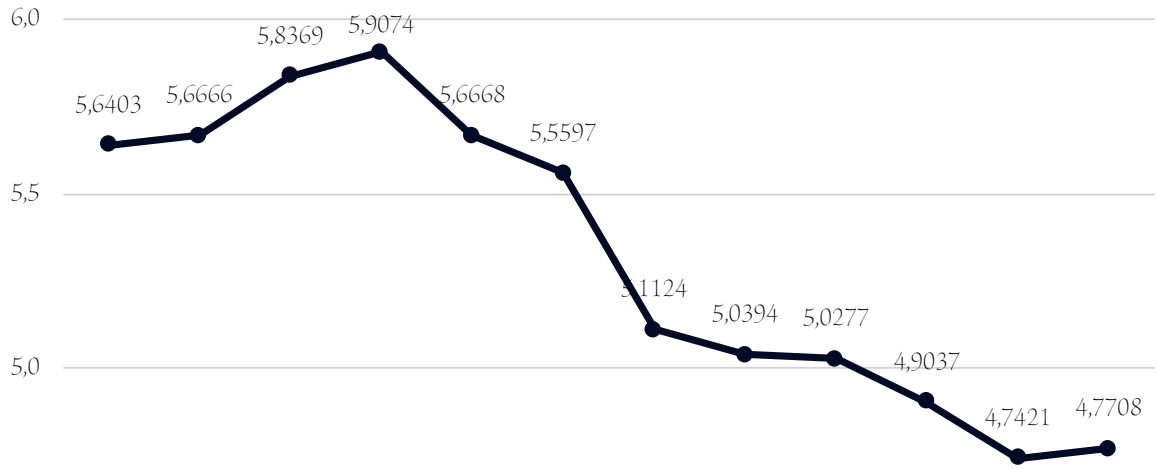

4,5

Q1.2015 Q2.2015 Q3.2015 Q4.2015 Q1.2016 Q2.2016 Q3.2016 Q4.2016 Q1.2017 Q2.2017 Q3.2017 Q4.2017 Źródło: Opracowanie wlasne na podstawie NBP (2018).

Wykres 4.

Imigracja, emigracja i migracja netto w Wielkiej Brytanii w latach 2003-2017 (w tys. osób)

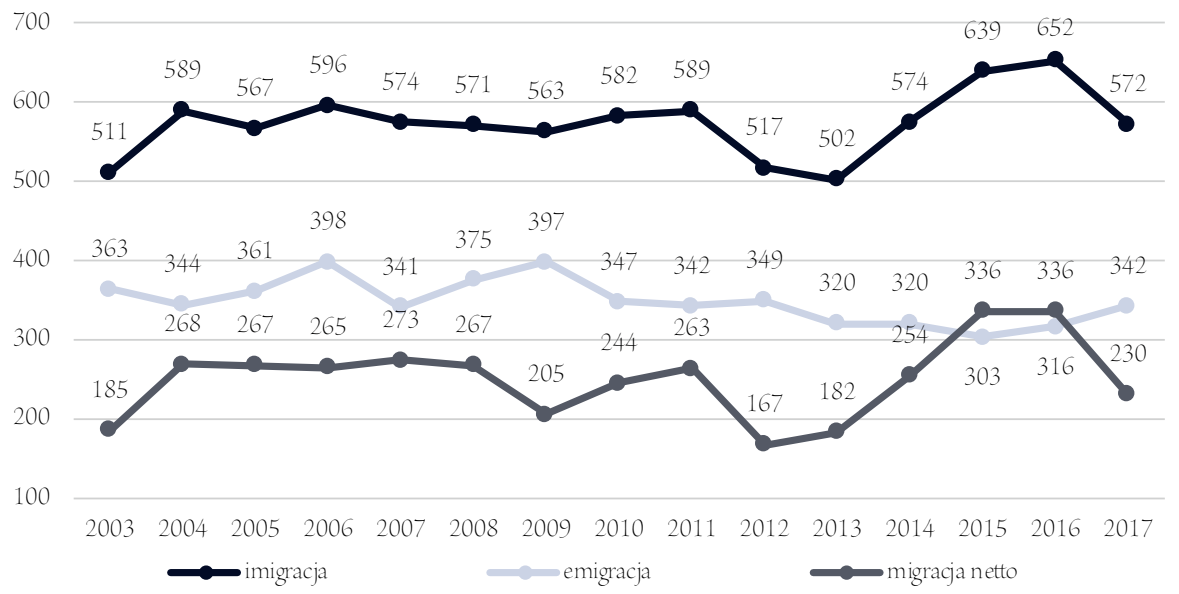

Źródło: Opracowanie własne na podstawie ONS (2018). 
Wykres 5.

Kwartalne odpływy BIZ z Wielkiej Brytanii, Niemiec i Stanów Zjednoczonych w latach 2015-2017 (w mln USD)

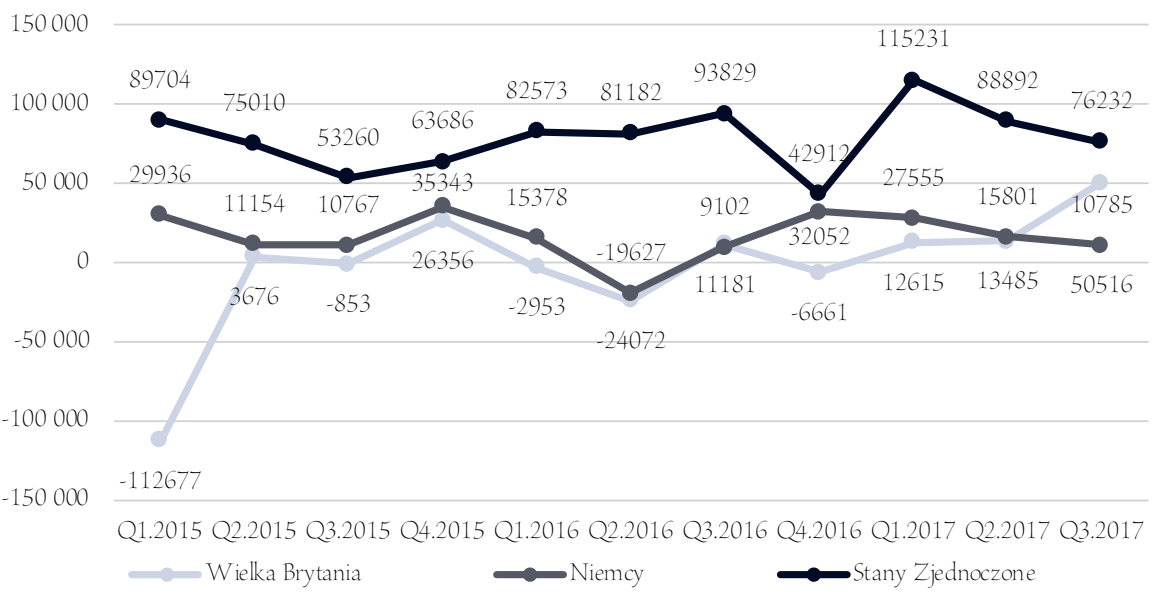

Źródło: Opracowanie własne na podstawie OECD (2018).

Wykres 6.

Kwartalne napływy BIZ do Wielkiej Brytanii, Niemiec i Stanów Zjednoczonych w latach 2015-2017 (w mln USD)

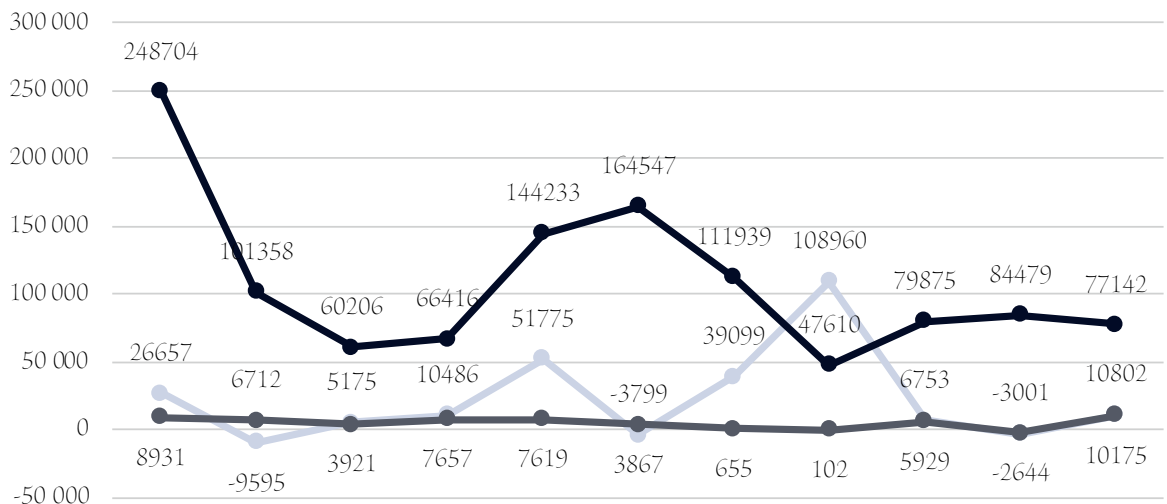

$-50000$

Q1.2015 Q2.2015 Q3.2015 Q4.2015 Q1.2016 Q2.2016 Q3.2016 Q4.2016 Q1.2017 Q2.2017 Q3.2017<smiles>C=CCCCCCCCC</smiles>

$\longrightarrow$ Niemcy

$\longrightarrow$ Stany Zjednoczone

Źródło: Opracowanie własne na podstawie OECD (2018). 
Wykres 7.

Struktura BIZ dokonywanych przez państwa UE w Wielkiej Brytanii pod względem sektorów gospodarki w 2016 roku (w\%)

25

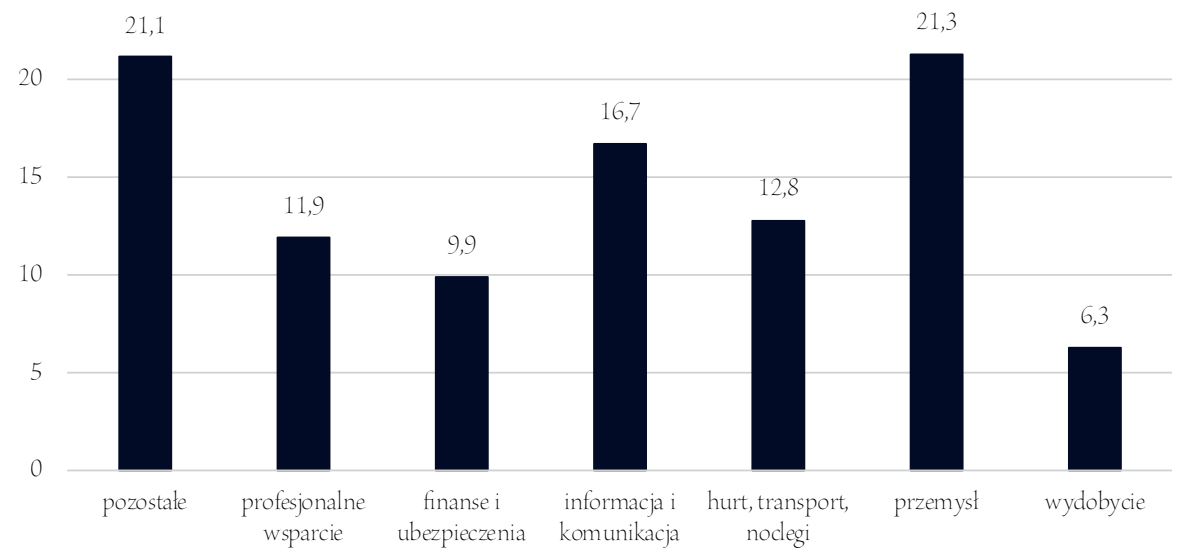

Żródło: Opracowanie własne na podstawie ONS (2018).

Wykres 8.

Struktura importu i eksportu Wielkiej Brytanii według poszczególnych państw w 2016 roku (w \%)

60

51,9

50

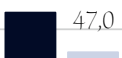

40

30

20

10

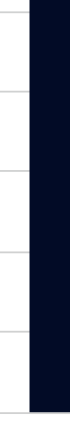

Unia Europejska

Stany Zjednoczone

- Import

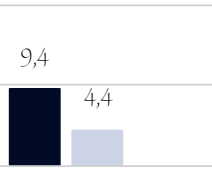

Chiny

Niemcy

Eksport

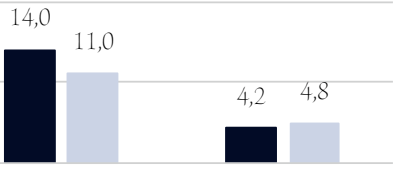

Szwajcaria

Źródło: Opracowanie własne na podstawie WTO (2018). 
The impact of the brexit on the Great Britain economy

\section{Abstract}

Motivation: In a referendum held on 23 June 2016, the British decided on Britain's withdrawal from the European Union (EU). So far, only two countries have separated from EU structures, i.e. Greenland and Algeria. Brexit analysis will allow to explain the procedures and consequences associated with the occurrence of a given country from EU structures. In addition, leaving the group by a highly developed country with a strong position in the international arena, can cause not only political, but also economic consequences for the whole Europe.

Aim: The aim of the article is to demonstrate the potential impact of brexit on particular macroeconomic variables reflecting the condition of the British economy. The analysis covered: the rate of economic growth measured by GDP, the inflation rate measured with the CPI (Consumer Price Index) index, the GBP/PLN exchange rate, migration processes, public finances, foreign direct investment (FDI) and the United Kingdom foreign trade.

Materials and methods: The various sources and research methods were used in the article. The theoretical part is based on scientific articles and Internet sources. The empirical material is data published by ONS, OECD and the Official Portal of the European Union. The applied research methods include descriptive analysis and analysis of selected macroeconomic indicators.

Results: The conducted analysis showed that brexit will undoubtedly have an impact on the condition of the UK economy, and the scale of the slowdown depends on the British government's choice of a model defining the level of connections with the EU market. The effects of brexit can include slower GDP growth, higher inflation, GBP depreciation, reduced inflow of immigrants and outflow of FDI to other countries.

Keywords: brexit; Great Britain; referendum

JEL: FOO; EOO; HOO 
